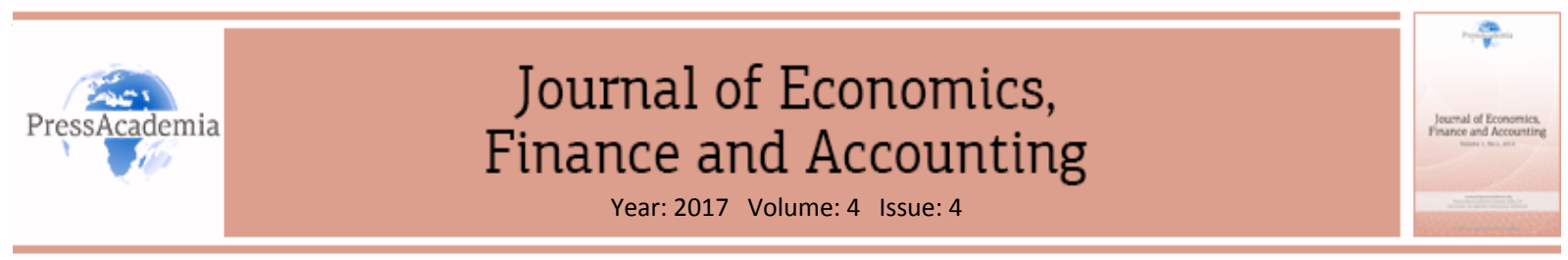

\title{
ANALYSIS OF UNEMPLOYMENT HYSTERESIS IN TURKEY: STRUCTURAL BREAK UNIT ROOT TEST
}

\author{
DOI: 10.17261/Pressacademia.2017.747
}

JEFA- V.4-ISS.4-2017(2)-p.368-376

\section{Aylin İdikut Ozpence ${ }^{1}$, Eren Ergen ${ }^{2}$}

${ }^{1}$ Pamukkale University, Faculty of Economics and Administrative Sciences, Denizli, Turkey. aidikut@pau.edu.tr

${ }^{2}$ Pamukkale University, Faculty of Economics and Administrative Sciences, Denizli, Turkey. eergen@pau.edu.tr

\section{To cite this document}

Ozpence, A.I. \& Ergen, E. (2017). Analysis of unemployment hysteresis in Turkey: structural break unit root test. Journal of Economics, Finance and Accounting (JEFA), V.4, Iss.4, p.368-376.

Permemant link to this document: http://doi.org/10.17261/Pressacademia.2017.747

Copyright: Published by PressAcademia and limited licenced re-use rights only.

\section{ABSTRACT}

Purpose- There are two basic approaches in the literature on the dynamic tendencies of unemployment. The first is the concept of the natural rate of unemployment put forward by Friedman (1968) and Phelps (1968). The second is dynamics path dependent concept of unemployment hysteresis, as explained by Blanchard and Summers (1986a, 1986b). Shocks in the economy cause permanent effects on unemployment according to in unemployment hysteresis hypothesis, while unemployment occurs at a certain rate according to the natural rate of unemployment approach. The aim of this paper is to determine whether unemployment hysteresis exist in Turkey.

Methodology- In this study, the existence of unemployment hysteresis in Turkey is tested using the monthly data for period of 2005m01$2016 \mathrm{~m} 11$. Lee-Strazicich (LS) test which of taken account structural breaks unit root tests is performed. In the analysis, both single break LS (2013) and double breaks LS (2003) tests is used.

Findings- While the natural of rate unemployment is at a stationary according to unit root tests, unemployment hysteresis is nonstationary. It means that the unemployment rate has been disclosed with past values. The results show that the unemployment hysteresis hypothesis is valid for Turkey when the analysed period is considered.

Conclusion- Unemployment rates in Turkey are unresisting to shocks. Unemployment rates are permanently affected by emerging shocks. Therefore policy makers should take into account to this situation when implementing employment policies.

Keywords: Natural rate of unemployment, unemployment hysteresis, structural breaks, unit root tests, Turkey.

JEL Codes: E24, C12, C22

\section{TÜRKIYE’DE IŞSIZLIK HISTERISININ ANALIZi: YAPISAL KIRILMALI BİRIM KÖK TESTi}

\section{ÖZET}

Amaç- İşsizliğin dinamik eğilimlerine yönelik literatürde iki temel yaklaşım bulunmaktadır. Bunlardan ilki Friedman (1968) ve Phelps (1968) tarafından ileri sürülen doğal işsizlik oranı kavramıdır. İkincisi ise Blanchard ve Summers (1986) tarafından açıklanan yol bağımlı işsizlik histerisi kavramıdır. Doğal işsizlik oranı yaklaşımına göre, işsizlik belli bir oranda gerçekleşirken işsizlik histerisi hipotezine göre de ekonomide meydana gelen şoklar işsizlik oranları üzerinde kalıcı etkiler bırakmaktadır. Bu çalışmanın amacı Türkiye'de işsizlik histerisinin var olup olmadığını belirlemektir.

Yöntem- Bu çalışmada 2005m1-2016m11 dönemine ait aylık veriler kullanılarak Türkiye'de işsizlik histerisinin varlığı sınanmıştır. Çalışmada yapısal kırılmaları dikkate alan Lee-Strazicich (LS) birim kök testleri yapılmıştır. Analizde hem tek kırılmalı LS (2013) hem de çift kırılmalı LS (2003) testler kullanılmıştır.

Bulgular- Birim kök testlerine göre doğal işsizlik oranı durağanken, işsizlik histerisi durağan değildir. Yani bu durum işsizlik oranının geçmiş değerlerle açıklandığını göstermektedir. Analiz dönemi dikkate alındığında uygulanan test sonuçlarına göre işsizlik histerisinin hipotezinin Türkiye için geçerli olduğu görülmektedir.

Sonuç- Türkiye'de işsizlik oranları şoklara karşı dirençli değildir. İşsizlik oranları ortaya çıkan şoklardan kalıcı olarak etkilenmektedir. Bu nedenle istihdam politikaları açısından politika uygulayıcıları işsizlik histerisini dikkate almalıdır.

Anahtar Kelimeler: Doğal işsizlik oranı, işsizlik histerisi, yapısal kırılmalar, birim kök testleri, Türkiye. JEL Kodları: E24, C12, C22 


\section{GiRiş}

İstihdam denildiğinde, tam istihdam ve eksik istihdam olmak üzere iki durum anlaşılmaktadır. Günümüzde ülkelerin temel amaçlarından birisi tam istihdamın sağlanması ve korunmasıdır. Bir ekonomide bulunan tüm üretim faktörlerinin tam olarak üretimde bulunması tam istihdam durumunu ifade etmektedir. Ülkenin tam istihdam durumunda bulunması ile milli gelir düzeyi arasında güçlü bir ilişki bulunmaktadır. Tam istihdam durumu bulunduğunda milli gelir artmaktadır. Eksik istihdam durumunda ise milli gelir azalmakta ve ekonomik büyüme negatif etkilenmektedir (Edizdoğan vd., 2013: 509). Tam istihdamın sağlanması ekonomik büyümeye yüksek katkıda bulunmaktadır. Tam istihdamın gerçekleşmesi ekonomik istikrarın olumlu yatırım iklimini belirleyen temel faktördür (Ulusoy, 2013: 26).

İşsizlik ve istihdam bir ülke ekonomisi için önem arz etmektedir. İşsizlik verileri ülkelerin karne notu olarak görülmektedir. 0 halde ülkelerin işsizlik oranlarını dikkatle incelemesi ve işsizlik oranlarının düşük kalması için çeşitli politikaları uygulamaları gerekmektedir. İşsizlik olgusu göründüğünden daha karmaşık eğilimler içerebilmektedir. Bu nedenle işsizlik için uygulanacak politikalardan önce bilinmesi gereken işsizliğin nasıl bir yapı içerdiğidir.

Ekonomide herhangi bir şok (talep ya da arz şokları) yaşandığında Friedman (1968) ve Phelps'in (1968) doğal oran hipotezine göre işsizlik üzerindeki etki geçici olurken, enflasyonu arttırmayan işsizlik oranı (NAIRU) ve işsizlik histerisi hipotezine göre bu etki kalıcıdır. Yani işsizlik oranı şoktan önceki döneme göre daha kalıcı hale gelmektedir.

Türkiye'de işsizlik histerisinin var olup olmadığının araştııılığı çalışmanın bundan sonraki bölümünde işsizliğin dinamik eğilimlerine yer verilecektir. İşsizlik histerisi üzerine gerçekleştirilen çalışmalar için bir literatür taraması yapılarak son olarak ampirik çalışmanın sonuçları incelenerek yorumlanmaktadır.

\section{2. işSizLiĞiN DINAMiK EĞiLiMLERI VE TÜRKIYE’DE IşSizLiK}

İşizliğin dinamik eğilimleri ile ilgili olarak literatürde iki önemli teori bulunmaktadır. Bunlardan ilki Friedman (1968) ve Phelps (1968) tarafından ileri sürülen doğal işsizlik oranı teorisidir. Diğeri ise NAIRU ve işsizlik histerisi hipotezidir (Güloğlu ve İspir, 2011: 205).

\subsection{Doğal İşsizlik Oranı ve NAIRU}

Parasal ücretler ile işsizlik arasındaki değiş tokuşun varlı̆̆ı Phillips (1958) tarafından ilk defa öne sürüldüğünde, Keynesyen ve Klasik iktisatçılar temelde para arzı ve talebini formülleştirmeyi paylaşırken sadece işgücü piyasasını modellemede (nominal ücretlerin işsizliğe verdiği tepki) farklılaşmaktadır. Bu farklılık fiyat ve ücretlerin sırasıyla katılık (rigidity) ya da yapışkanlık (stickiness) ve tam esneklik özelliği taşımalarıdır. Klasik iktisatçılara göre özellikle gelişmiş ülkelerde kitlesel işsizlik, sistemin rassal ve geçici bir sapması olarak görülürken Keynesyenlere göre rassal ve geçici değildir (Modigliani, 2003: 3).

Friedman (1968) ve Phelps (1968) doğal (denge) işsizlik oranı kavramını ileri sürmüştür. Friedman (1968) yaptığı analizde istihdam piyasasını ele almaktadır. Friedman'a göre herhangi bir anda reel ücret seviyelerinin yapısındaki denge ile tutarlı bir ilişki sergileyen belirli bir oranda işsizlik seviyesi bulunmaktadır. Bu seviyedeki işsizlik oranında reel ücretler, sermaye oluşumu, teknolojik gelişmeler vb. uzun vadede kaldıkça, ekonomide normal bir oranda işsizlik bulunmaktadır. İşsizlik oranlarının düşük olması reel ücretlerde yukarı yönlü bir baskı oluştururken, işsizlik oranlarının yükselmesi ise reel ücretlerin aşağı yönlü baskı ile karşılaşmasını sağlamaktadır. Doğal işsizlik oranı Walrasyan Genel Denge denklemleri ile ilişkilidir. Ancak Friedman burada doğal işsizlik oranı ifadesi ile işsizlik oranının değişmez veya değiştirilemez olduğunu söylememektedir. Doğal işsizlik seviyesini belirleyen piyasa özellikleri ve politikalar bulunmaktadır (Friedman, 1968: 8-9).

Burada işsizlik oranı, doğal işsizlik oranı ve fiili işsizlik oranının farkının bir fonksiyonu şeklinde ifade edilmektedir. Gerek Friedman (1977: 458) ve gerekse Phelps (1967: 254-255) Adaptif (adaptive) beklentileri dikkate alarak bireylerin enflasyon beklentilerinin enflasyonu nasıl etkileyeceği üzerinde durmuşlardır. Kısa dönemde işsizlik ve enflasyon arasında değiş tokuş olabileceğini ancak uzun dönemde özellikle işsizliğin eski düzeyine geri geleceğini belirtmektedirler.

Modigliani ve Papademos, artan işsizlik oranlarına ücret enflasyonu da eklenince doğal işsizlik oranı yerine, enflasyonu arttırmayan işsizlik oranı ${ }^{1}$ (NAIRU) hipotezini ön plana çıkarmıştır (Yalçınkaya ve Kaya, 2017: 3). Kısa dönemde enflasyon ile işsizlik arasında değiş-tokuş (tradeoff) olduğu kabul edildikten sonra, istikrarlı bir enflasyon ile tutarlı bir düzeyde işsizlik olmalıdır. Bu istikrarı açıklayan NAIRU zaman içinde giderek gündemden düşmüştür. Uygulanan politikaların ve demografik faktörlerin yanında esas etkinin verimlilikteki artıştan kaynaklandığı söylenebilir (Ball ve Mankiw, 2002: 115).

\footnotetext{
${ }^{1}$ NAIRU (Non-Accelerating Inflation Rate of Unemployment), ilk olarak Franco Modigliani ve Lucas Papademos (1975: 142) tarafindan (NonInflationary Rate of Unemployment) NIRU adı altında geliştirilmiştir. Tobin (1997: 7) bu kavramı NAIRU olarak ifade eden ilk kişidir. NAIRU kavramı bazı iktisatçılara göre yaklaşık olarak doğal işsizlik oranı ile aynı anlamda kullanııırken (Ball and Mankiw, 2002: 115) diğerlerine göre farklı anlamlar içermektedir (Tobin, 1997:1).
} 
Tobin (1997) doğal oran ve NAIRU kavramının iç içe geçtiğini ancak bu iki kavramın birbirinden farklı olduğunu belirtmektedir. Tobin'e göre (1997: 1);

NAIRU aşırı talep ve arz taşmaları durumunda birçok işgücüne sahip bir ekonominin makro sonucudur. NAIRU aşırı talep fazlasından kaynaklı enflasyon artırıcı ve aşırı arz fazlasından kaynaklı enflasyon düşürücü baskılar arasında genel dengeyi temsil etmektedir. Doğal oran ise piyasaların temizlendiği Walrasyan genel dengenin bir özelliğidir. ikisinin de belirleyicileri teorik olarak farklı olduğu için politik sonuçları da farklıdır.

Friedman, doğal oranın işgücü piyasasındaki aksaklıklar nedeniyle zamanla değişebileceğini varsaymaktadır. NAIRU'da da yine işgücü piyasasındaki aksaklıklar, kurumlar, ekonomik şoklar, verimliliğin düşmesi ve küreselleşme nedeniyle değişimler yaşanmaktadır. 1960 ve 2000 yılları arasında yaşanan NAIRU'daki değişimler ise bu kavramın eleştirilere maruz kalmasına neden olmuştur (Ball, 2009: 5).

Enflasyonu arttırmayan işsizlik oranının ülke konjonktüründe meydana gelen şoklardan etkilenmesi, enflasyon ve işsizlik arasındaki ilişkiyi yeniden açıklayan işsizlik histerisi hipoteziyle açıklanmaya çalışılmışır (Yalçınkaya ve Kaya, 2017: 3).

\section{2. İşsizlik Histerisi Hipotezi}

Histeri kavramı Ewing'in (1881) çalışmasına kadar uzanmasına rağmen, ilk olarak, ekonomi teorisi içinde kullanan ve dinamik modelleme konusunda çalışanların temel zorluklarını tartışan Samuelson (1965) olmuştur. Phelps (1972) işsizlik teorisi içinde histeri terimini tanıtmış ancak Blanchard ve Summers (1986a: 16) tarafından sunulan içeridekiler/çalışanlardışarıdakiler/ işsizler (insider-outsider) modeliyle teorinin literatürde ilgi uyandırmasını sağlamıştır (Røed,1996:590).

1980'lere kadar hem klasik hem de Keynesyen iktisat, denge istihdam konusunda histeriyi dışlarken doğal dengeyi dikkate almıştır. Schumpeter and Georgescu-Roegen gibi iktisatçılar ise ekonomik sistemlerin davranışlarını anlamada histeri kavramının gerekli olduğunu belirtmiştir (Cross, Hutchinson and Yeoward, 1990: 93). Histeri etkisinin temel fikri, denge işsizlik düzeyinin, fiili işsizliğin tarihçesine bağlı olmasıdır (Blanchard ve Summer, 1986b: 3). Histeri uzun dönem işsizlik hareketlerinin sonuçlarını göstermektedir. Buna göre, ekonomide yaşanacak herhangi bir şok neticesinde işsizlik oranları eski seviyesini koruyamayacaktır. Şoktan önceki döneme göre ya daha düşük ya da daha yüksek bir oranda dengelenecektir.

Yeni Keynesyenler işsizlik histerisi etkisene neden olan faktörleri açıklamak için süre (duration) teorisi, insider-outsider (içerdekiler/çalışanlar-dışardakiler/işsizler teorisi) (Blanchard ve Summer, 1986b: 2) ve etkinlik ücreti teorisi geliştirmiştir. Bir işin süresini her iki tarafın da iş sözleşmesine taraf olma meselesidir şeklinde tanımlayan Hall (1979: 158), işverenlerin genellikle çok kısa işlerde işe alım ve eğitim masrafları nedeniyle anlaşmaya isteksiz olduğunu vurgulamaktadır. Hall'a göre bir eş maliyet (isocost curve) doğrusu kapsamında işverenler orta süreli işlerde daha yüksek bir ücreti tercih etmektedir. Çünkü daha kısa süreli işlerde personel maliyetleri verimliliği düşürürken uzun süreli işler istihdam esneksizliğine neden olmaktadır.

Blanchard ve Summer (1986a) Avrupa Birliği için yaptıkları çalışmalarında histeri etkisine neden olan faktörleri içerdekiler/çalışanlar-dışardakiler/işsizler modeli ile açıklamaktadır. Teori özellikle ücret pazarlıklarından kaynaklanmaktadır. Çalışmada sunulan merkezi hipoteze göre, birliğe üyelik kaygılarından kaynaklanan histeri Avrupa'daki mevcut depresyonun ve genel olarak sürekli yüksek işsizliğin açıklanmasında önemli rol oynamaktadır. Burada önemli hususun istihdam edilen kişiler ile işsizler arasındaki ücret belirleme sürecinde yaşanılan asimetri olduğu görülmektedir. İşsizler haklarını kaybetmiş durumdadır ve ücretler istihdam edilenlerin işlerini sağlamak adına oluşturulmaktadır. Bu noktada ekonomide meydana gelen bir şok istihdamın azalmasına ve işsizliğin artmasına yol açmaktadır. Bu durum istihdam edilenlerin sayısını ve denge ücret oranını değiştirerek işsizlik histerisine yol açmaktadır (Blanchard ve Summer, 1986a: 16-29).

İktisadi düşüncelerin genelinde emeğin verimliliği genellikle ücret düzeyinden bağımsız kabul edilirken, etkinlik ücretinde emeğin verimliliği reel ücret düzeyine bağlıdır. Emeğin verimliliğinin neden reel ücrete tabi olduğu ise farklı modellerle açıklanmaktadır. Bunlar ücret düzeyi ve işi kaytarma modeli (ücreti düşük bulan iş̧̧ilerin tepkisi), işçi devri modeli (firmaların yeni bir işçinin maliyetini göz önüne alarak çalışanlarına daha yüksek ücret vermesi), tersten seçim modeli (yetenekli iş̧̧iler için yüksek ücret) ve son olarak sosyolojik modellerdir (firmalar sadece kar maksimizasyonu peşinde koşmayabilir, düşük verimli iş̧̧ilere de yüksek ücret verebilir) (Hiç-Birol, 2006:150-152).

Tıpkı NAIRU'da yaşanan sıkıntılar gibi histeride de temel sorun işgücü piyasasının yapısı, sendikalaşmanın varlığı, işsizliği arttıran olumsuz şokların etkisi ve içerdekiler/çalışanlar-dışardakiler/işsizler sorunun sonucu olup olmadığıdır. 1970'lerde Avrupa ekonomileri yükselen petrol fiyatları, verimliliğin düşmesi, hızla artan vergi oranları ve kısa dönemde ücretlerin rijit olması gibi şoklar yaşamış ve bu tip şokların her biri işsizliği yaratmıştır. 1980'lerde ise genişletici para politikaları yanında daraltıcı maliye politikalarının uygulanması gibi toplam talep şokları yaşayan Avrupa ekonomilerinde istihdam edilenlerin ücret talepleri doğrultusunda işsizlik daha derinleşmiştir. Artık herhangi bir şok yaşanmasa da içerdekilerin/çalışanların ücretlerini belirleme gücünden dolayı işsizlik yüksektir. (Blanchard ve Summer, 1986a: 71-72). 


\subsection{Türkiye'de İşsizlik Oranları}

Türkiye'nin işsizlik oranları, yapısal ve konjonktürel sebeplerden dolayı artmaktadır. Dışa açılma politikalarında Türkiye'de işsizlik önemli bir problem olarak görülmezken, $1980^{\prime}$ li yıllardan sonra makro ekonomik çerçevede büyük bir sorun olmaya başlamıştır (Bayrakdar, 2015: 47). Grafik 1 Türkiye için 2005 yılından itibaren işsizlik oranlarının seyrini göstermektedir.

Küresel krizin yaşandığı yıl olan 2008'e kadar işsizlik oranlarında yatay bir seyir mevcutken, 2008'de yaşanılan küresel krizin etkisiyle birlikte işsizlik oranlarından ani bir artış yaşanmıştır. Krizin etkilerinin ortadan kalkmasıyla birlikte 2011 yılında kadar yaşanılan düşüş bu yıldan itibaren yerini artışa bırakmıştır.

Grafik 1: Türkiye'de İşsizlik Oranları, (2005-2016)

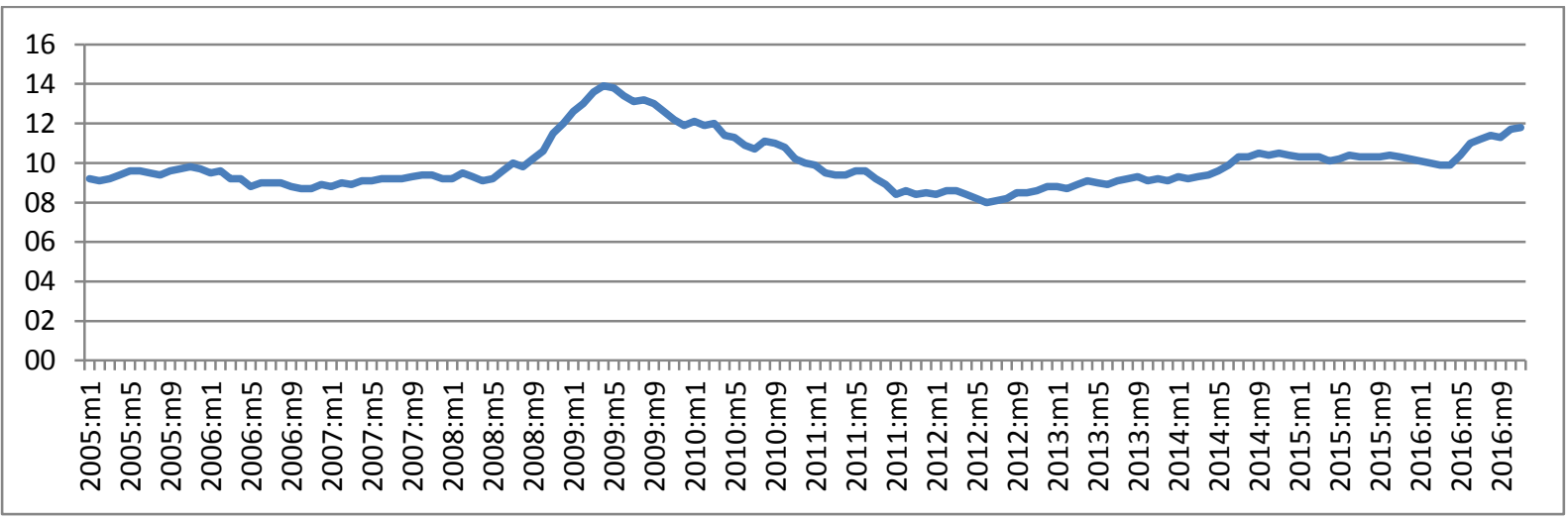

\section{LITERATÜR TARAMASI}

Türkiye için Yıldırım (2011) tarafından yapılan çalışmada Bai-Perron birim kök testi kullanılmış ve işsizlik histerisinin varlığı sonucuna ulaşılmıştır. Barışık ve Çevik'in 1923-2006 yıllarını kapsayan çalışmasında da işsizlik histerisi etkileri saptanmıştır. Bayrakdar (2015) çalışmasında Türkiye için işsizlik histerisinin geçerli olduğunu bulmuştur. Berk ve Çağlar'a (2016) göre Türkiye'nin işsizlik histerisinin etkisinde bulunduğu görülmektedir. Bayat vd. (2013) ise işsizlik oranlarının aşağı yönlü katılık gösterdiğini tespit etmiştir. Yılancı (2009) çalışmasında Türkiye'de işsizlik oranları üzerinde meydana gelen şokların doğal işsizlik oranından sapmalara neden olduğunu belirtmektedir.

Güloğlu ve İspir 2011 yılında Türkiye için yaptıkları çalışmalarında işsizlik oranı üzerinde meydana gelen şokların etkisinin uzun sürdüğünü ancak kalııı olmadığını tespit etmişlerdir. Baydur ve Süslü (2015) Türkiye'de işsizlik oranlarının talep yetersizliğinden kaynaklandığını ortaya koymuştur. Akçay (2013) doğrusal olmayan birim kök testlerinin işsizlik hipotezi üzerine güçlü kanıtlar bulurken, doğrusal birim kök testlerinin başarısız olduğu sonucuna ulaşmıştır.

Strazicich vd. (2001) Fransa, Almanya, İtalya, İspanya ve İngiltere için yaptığı çalışmasında ilgili ülkelerin tamamında işsizlik histerisinin varlığını bulmuştur. Gustavsson ve Ostherholm Avustralya, Kanada, Finlandiya, İsveç ve ABD örneklerini ele almış ve Avustralya dışındaki ülkelerde işsizlik histerisi hipotezinin bulunmadığı sonucuna ulaşmıştır. Blanchard ve Summers (1986) yaptıkları çalışmada Fransa, İngiltere, Almanya ve ABD'yi ele almaktadır. DF ve ADF birim kök analizleri kullanılarak yapılan çalışmada Fransa, İngiltere ve Almanya için işsizlik histerisinin geçerli olduğu bulunurken, ABD için işsizlik histerisi hipotezinin varlığı ret edilmiştir. Romero-Avila ve Usabiaga'nın (2007) çalışmalarında İspanya için işsizlik histerisi kabul edilirken, ABD için yapısalcı hipotezin varlığı bulunmaktadır. Arı vd. (2013) yaptıkları çalışmada Doğu Asya ve Pasifik ülkeleri incelenmektedir. Incelenen ülkelerin çoğunda konjonktürel dalgalanmaların işsizlik oranları üzerinde kalıcı etkiler yaratmadığı bulunmuştur.

Tablo 1: Literatür Taraması

\begin{tabular}{|l|l|l|l|l|}
\hline $\begin{array}{l}\text { Yazar / Çalışmanın } \\
\text { Yılı }\end{array}$ & $\begin{array}{l}\text { Analizin Yapıldığı } \\
\text { Ülke }\end{array}$ & $\begin{array}{l}\text { Analizin } \\
\text { Kapsadığı } \\
\text { Yıllar }\end{array}$ & $\begin{array}{l}\text { Kullanılan } \\
\text { Ekonometrik } \\
\text { Yöntemler }\end{array}$ & Bulgular \\
\hline $\begin{array}{l}\text { Güloğlu ve İspir } \\
\text { (2011) }\end{array}$ & Türkiye & $1998-2008$ & Panel Birim Kök & $\begin{array}{l}\text { Doğal işsizlik oranı teorisinin özel bir } \\
\text { durumu olarak iktisat literatüründe } \\
\text { kullanılan, geçici şokların işsizlik oranı } \\
\text { üzerindeki etkilerinin uzun süre devam } \\
\text { ettiğini fakat kalıcı olmadığını söyleyen } \\
\text { görüşü destekler nitelikte sonuca } \\
\text { ulaşııımıştır. }\end{array}$ \\
\hline
\end{tabular}




\begin{tabular}{|c|c|c|c|c|}
\hline $\begin{array}{l}\text { Strazicich vd. } \\
(2001)\end{array}$ & $\begin{array}{l}\text { Fransa, Almanya, } \\
\text { İtalya, İspanya, } \\
\text { İngiltere }\end{array}$ & 1955-1999 & $\begin{array}{l}\text { Panel LM Birim } \\
\text { Kök Testi ve } \\
\text { Yapısal Kırılmalı } \\
\text { Panel LM Testi }\end{array}$ & $\begin{array}{l}\text { İncelenen ülkelerin tamamında analiz } \\
\text { edilen yıllar için işsizlik histerisi } \\
\text { bulunmuştur. }\end{array}$ \\
\hline Yıldırım (2011) & Türkiye & $1923-2010$ & $\begin{array}{l}\text { Bai-Perron Birim } \\
\text { Kök Testi }\end{array}$ & $\begin{array}{l}\text { Incelenen yıllar için Türkiye'de işsizlik } \\
\text { histerisinin varlığı bulunmaktadır. }\end{array}$ \\
\hline $\begin{array}{l}\text { Gustavsson ve } \\
\text { Osterholm (2006) }\end{array}$ & $\begin{array}{l}\text { Avustralya, } \\
\text { Kanada, } \\
\text { Finlandiya, İsveç } \\
\text { ve ABD }\end{array}$ & $\begin{array}{l}\text { Avustralya: } \\
\text { 1978-2005, } \\
\text { Kanada: } \\
\text { 1976-2005, } \\
\text { Finlandiya: } \\
\text { 1960-2004, } \\
\text { İsveç: 1970- } \\
\text { 2004, ABD: } \\
\text { 1948-2005 }\end{array}$ & $\begin{array}{l}\text { Doğrusal } \\
\text { Olmayan Birim } \\
\text { Kök Testleri }\end{array}$ & $\begin{array}{l}\text { Yapılan çalışmada Avustralya'da işsizlik } \\
\text { histerisinin varlığı saptanırken ilgili } \\
\text { ülkelerin geri kalanında işsizlik } \\
\text { histerisinin geçerli olmadığı } \\
\text { bulunmuştur. }\end{array}$ \\
\hline $\begin{array}{l}\text { Barışık ve Çevik } \\
(2008)\end{array}$ & Türkiye & $1923-2006$ & $\begin{array}{l}\text { Bai-Perron, Zivot } \\
\text { Andresws, GPH, } \\
\text { RMLP, RGSP, MLP }\end{array}$ & $\begin{array}{l}1968 \text { yılında kırılma saptanan } \\
\text { çalışmada, işsizlik histerisi etkisinin } \\
\text { varlığı bulunmuştur. }\end{array}$ \\
\hline $\begin{array}{l}\text { Blanchard ve } \\
\text { Summers (1986) }\end{array}$ & $\begin{array}{l}\text { Fransa, İngiltere, } \\
\text { Almanya, ABD }\end{array}$ & $1953-1984$ & $\begin{array}{l}\text { DF ve ADF Birim } \\
\text { Kök Analizleri }\end{array}$ & $\begin{array}{l}\text { Yapılan Çalışmada Fransa, İngiltere ve } \\
\text { Almanya için işsizlik histerisinin varlığı } \\
\text { saptanırken, ABD için ise işsizlik } \\
\text { histerisinin varlığı bulunamamıştır. }\end{array}$ \\
\hline Bayrakdar (2015) & Türkiye & $2000-2013$ & $\begin{array}{l}\text { Birim Kök } \\
\text { Testleri, Lee- } \\
\text { Strazicich }\end{array}$ & $\begin{array}{l}\text { Yapılan çalışmada Türkiye için işsizlik } \\
\text { histerisi varlığı saptanmıştır. }\end{array}$ \\
\hline $\begin{array}{l}\text { Romero-Avila ve } \\
\text { Usabiaga (2007) }\end{array}$ & İspanya ve $A B D$ & $1976-2004$ & $\begin{array}{l}\text { Kırılmalı LM Birim } \\
\text { Kök Testleri }\end{array}$ & $\begin{array}{l}\text { İspanya için işsizlik histerisi etkileri } \\
\text { saptanan çalışmada, ABD için yapısalcı } \\
\text { hipotez kabul edilmiştir. }\end{array}$ \\
\hline $\begin{array}{l}\text { Baydur ve Süslü } \\
\text { (2015) }\end{array}$ & Türkiye & $2000-2013$ & ARDL & $\begin{array}{l}\text { Türkiye için işsizliğin talep yetersizliği } \\
\text { nedeniyle etkilendiği sonucuna } \\
\text { ulaşılmaktadır. }\end{array}$ \\
\hline $\begin{array}{l}\text { Berk ve Çağlar } \\
\text { (2016) }\end{array}$ & Türkiye & $1988-2014$ & $\begin{array}{l}\text { LM Tipi Tek } \\
\text { Kırılmalı ve LM } \\
\text { Tipi Çift Kırılmalı } \\
\text { Testler }\end{array}$ & $\begin{array}{l}\text { Çalışmada Türkiye'de incelenen yıllar } \\
\text { için işsizlik oranları üzerinde meydana } \\
\text { gelen şokların kalıcı etkiler içerdiği } \\
\text { bulunmuştur. }\end{array}$ \\
\hline Bayat vd. (2013) & Türkiye & $1923-2011$ & $\begin{array}{l}\text { Birim Kök } \\
\text { Testleri, BDS } \\
\text { Testi, Doğrusal } \\
\text { Olmama, Markov } \\
\text { Rejim Değişim } \\
\text { Modeli }\end{array}$ & $\begin{array}{l}\text { İşsizlik oranı aşağı doğru katılık } \\
\text { göstermiş, başka bir ifadeyle işsizliğin } \\
\text { rejim değiştirerek \%7'nin üstünde } \\
\text { kalıcı olduğu saptanmıştır. }\end{array}$ \\
\hline Akçay (2013) & Türkiye & $2005-2013$ & $\begin{array}{l}\text { Threshold } \\
\text { Autoregressive } \\
\text { (TAR) }\end{array}$ & $\begin{array}{l}\text { Doğrusal olmayan birim kök testinin, } \\
\text { doğal işsizlik hipotezinin lehine güçlü } \\
\text { kanıtlar bulunurken, standart doğrusal } \\
\text { birim kök testlerinin başarısız olduğu } \\
\text { saptanmıştır. }\end{array}$ \\
\hline Arı vd. (2013) & $\begin{array}{l}\text { Doğu Asya ve } \\
\text { Pasifik Ülkeleri }\end{array}$ & $1985-2011$ & Panel Birim Kök & $\begin{array}{l}\text { İncelenen ülkelerin çoğunluğunda } \\
\text { işsizlik histerisinin olmadığı, bu } \\
\text { sebeple konjonktürel dalgalanmaların } \\
\text { bu ülkelerdeki işsizlik oranları üzerinde } \\
\text { kalıcı bir etki yaratmadığı söylenebilir. }\end{array}$ \\
\hline Yılancı (2009) & Türkiye & $1923-2007$ & $\begin{array}{l}\text { Perron, Zivot- } \\
\text { Andrews, } \\
\text { Lumsdaine- } \\
\text { Papell, LM Birim } \\
\text { Kök Testleri }\end{array}$ & $\begin{array}{l}\text { Çalışmada ulaşılan bulgular, işsizlik } \\
\text { oranlarında meydana gelen şokların } \\
\text { doğal işsizlikten sapmalara neden } \\
\text { olduğunu ve bu sapmaların süreklilik } \\
\text { gösterdiğini desteklemektedir. }\end{array}$ \\
\hline $\begin{array}{l}\text { Yalçınkaya ve Kaya } \\
\text { (2017) }\end{array}$ & 28 OECD Ülkesi & $1980-2015$ & $\begin{array}{l}\text { LM, İinci Nesil } \\
\text { Panel Birim Kök, }\end{array}$ & $\begin{array}{l}\text { Ülkelerin büyük bölümünde, yapısal } \\
\text { kırılmaları dikkate almayan panel birim }\end{array}$ \\
\hline
\end{tabular}




\begin{tabular}{|c|c|c|c|c|}
\hline & & & $\begin{array}{l}\text { Yapısal Kırılmalı } \\
\text { CADF ve SURADF, } \\
\text { Panel KPSS }\end{array}$ & $\begin{array}{l}\text { kök testlerinin işsizlik histerisini, } \\
\text { yapısal kırılmaları dikkate alan testlerin } \\
\text { ise doğal işsizlik oranı hipotezini } \\
\text { desteklediği, şokların her ikisinde de } \\
\text { meydana geldiği ancak bu şokların } \\
\text { işsizlik oranı üzerinde etkilerinin kalıcı } \\
\text { nitelikte olmadığı belirtilmektedir. }\end{array}$ \\
\hline $\begin{array}{l}\text { Timurlenk ve Başar } \\
\text { (2012) }\end{array}$ & Türkiye & $\begin{array}{l}2000: 1- \\
2007: 4\end{array}$ & $\begin{array}{l}\text { Gordon'un üçlü } \\
\text { modeline göre } \\
\text { Kalman filtresi } \\
\text { yaklaşımı }\end{array}$ & $\begin{array}{l}\text { Çalışmada incelen dönem için \%9,5 } \\
\text { dolaylarında küçük dalgalanmalar } \\
\text { sergileyen NAIRU tahminleri elde } \\
\text { edilmiştir. }\end{array}$ \\
\hline
\end{tabular}

\section{VERI VE YÖNTEM}

Bu çalışmada Türkiye'de işsizlik histerisinin varlığı analiz edilmektedir. Analizde Türkiye'nin işsizlik oranları aylık olarak incelenmektedir. Bu doğrultuda veriler TÜiK'ten alınmıştır. TüiK'ten elde edilen veriler, 15 yaş üzeri ve mevsim etkilerinden arındırımış temel işgücü göstergelerinden elde edilmiştir. Analizde kullanılan veriler 2005:m1 ve 2016:m11 dönemini kapsamaktadır. İşsizlik verileri ise Türkiye'de işsizlik verilerinin hesaplanmasında yapılan değişiklik nedeniyle ampirik çalışmalar için sadece 2005 yılından itibaren anlamlıdır. Daha önceki yıllara ait veriler yeni hesaplama yöntemi ile uyumlaştırılmamıştır.

İşizlik teorileri arasında karar vermek için genellikle birim kök testleri uygulanmaktadır. Birim kök içerdiği ifade edilen histeri hipotezinin reddi, yapısal kırılmaları içermesi halinde yapısalcı hipotezi, içermemesi durumunda ise doğal işsizlik oranı hipotezinin kabul edilmesi gerekmektedir (Yılancı, 2009: 325).

Bu çalışmada yapısal kırılmalı birim kök analizi için Lee ve Strazicich (2013) tarafından geliştirilen tek kırılmalı test kullanılmaktadır. Yapısal kırılmalı modelin oluşturulmasında (1) nolu model kullanılmaktadır.

$$
y_{t}=\delta Z_{t}+X_{t}, X_{t}=\beta X_{t-1}+\epsilon_{t}
$$

$Z_{t}$ ile dışsal değişkenler ifade edilmektedir. Birim kökün test edilmesinde yokluk hipotezi $\beta=1$ şeklinde oluşturulmaktadır. Sabitte kırılmanın test edilmesi için oluşturulan Model A $Z_{t}=\left[1, t D_{t}\right]^{\prime}$ şeklinde tanımlanmaktadır.t $\geq T_{B}+1$ ve diğer durumlarda sıfır olması durumunda $D_{t}=1$ değerini almaktadır. $T_{B}$ ile yapısal kırılmanın zaman periyodu ifade edilmektedir ve $\delta=\left(\delta_{1}, \delta_{2}, \delta_{3}\right)$. Sabit ve trend için kırılmanın test edilmesinde ise Model C kullanılmaktadır. Model C $Z_{t}=\left[1, t D_{t}, D T_{t}\right]^{\prime}$ şeklinde tanımlanmaktadır. $t \geq T_{B}+1$ ve diğer durumlarda sıfır olması durumunda $D_{t}=t-T_{B}$ değerini almaktadır.

LM test stratejilerine göre yapısal kırılmalı birim kök testinin gözlenmesinde (2) nolu regresyon kullanılmaktadır.

$$
\Delta y_{t}=\delta^{\prime} \Delta Z_{t}+\phi \bar{S}_{t-1}+u_{t}
$$

(2) nolu denklemde gösterilen $\bar{S}_{t}=y_{t}-\bar{\Psi}_{x}-Z_{t} \bar{\delta}, t=2, \ldots, T ; \bar{\delta}$ olmak üzere regresyonda var olan $\Delta y_{t}$ regresyonunun $\Delta Z_{t} ; \bar{\Psi}_{x}$ kısıtıdır. Birim kök yokluk hipotezi $\phi=0$ şeklinde oluşturulmaktadır. (3) nolu denklemde yokluk hipotezi gösterilmektedir.

$$
\tilde{\tau}=\text { istatistik değeri ile yokluk hipotezi sınanmaktadır, } \phi=0
$$

Mümkün olan tüm kırımaların en küçük değere sahip olanının seçilmesi ile yapısal kırılma tarihi belirlenmektedir. Kırılmanın tahmin edilmesinde (4) nolu denklem kullanılmaktadır.

$$
\text { unemp } \tilde{\tau}(\tilde{\lambda})=\text { unemp } \tilde{\tau}(\lambda), \quad \lambda=T_{B} / T \text { ve } \lambda \in[0,1]
$$

Elde edilen bulguların güvenirliliğinin arttırılması için çalışmada ayrıca Lee ve Strazicich (2003) tarafından geliştirilen ve çift kırılmaya izin veren LM birim kök test istatistiği kullanılmaktadır. İki kırılmalı LM birim kök test istatistiğini tahmin etmek için (5) nolu denklem tahmin edilmektedir.

$$
\Delta y_{t}=\delta^{\prime} \Delta Z_{t}+\phi \bar{S}_{t-1}+\mu_{t}
$$

(5) nolu denklemde gösterilen $\bar{S}_{t}=y_{t}-\bar{\Psi}_{x}-Z_{t} \bar{\delta}, t=2, \ldots, T ; \bar{\delta}$ olmak üzere regresyonda var olan $\Delta y_{t}$ regresyonunun $\Delta Z_{t} ; \bar{\Psi}_{x}$ iki kırılmaya izin verecek şekilde düzenlenmektedir. Hem sabit hem trend için iki kırılmanın test edilmesinde gölge değişkenler kullanılmaktadır. Model A için $Z_{t}=\left[1, t, D_{1 t}, D_{2 t}\right]^{\prime}$ ve Model C için $Z_{t}=\left[1, t, D_{1 t}, D_{2 t}, D T_{1 t}, D T_{2 t}\right]^{\prime}$ olarak tanımlanmaktadır. Birim kök testinin boş hipotezi $\phi=0$ olarak tanımlanmaktadır. Kırılma tarihleri $T \rightarrow \infty$ durumunda formülü ile $T_{B j} / T \rightarrow \lambda_{j}$ hesaplanmaktadır. LM test istatistikleri ise denklem (6a) ve (6b) ile gösterilmektedir. 


$$
\begin{aligned}
& \bar{\rho}=T \phi, \\
& \tilde{\tau}=t-i s t a t i s t i k \text { değer } i \text { boş hipotezin sınamaktadır } \phi=0
\end{aligned}
$$

Test istatistiği yapısal kırılmalı birim köklü seri temel hipotezinin sınanmasında kullanılmaktadır. Ulaşılan test istatistiği Lee ve Strazicich (2003) tarafından oluşturulan tablo değerleri ile karşılaştırılarak karar verilmektedir (Lee and Strazicich, 2003: 1082-1083, Lee and Strazicich, 2013: 2485-2487).

\section{BULGULAR VE TARTIŞMA}

Tablo 2 ADF birim kök sonuçlarını göstermektedir. Tablo 2'de yer alan sonuçlara göre işsizlik oranı hem sabitli modelde hem de sabitli ve trendli modelde seviyesinde birim kök içermektedir. İşsizlik oranları serisinin \%5 anlam düzeyinde birinci derecede durağan olduğu görülmektedir.

Tablo 2: ADF Birim Kök Sonuçları

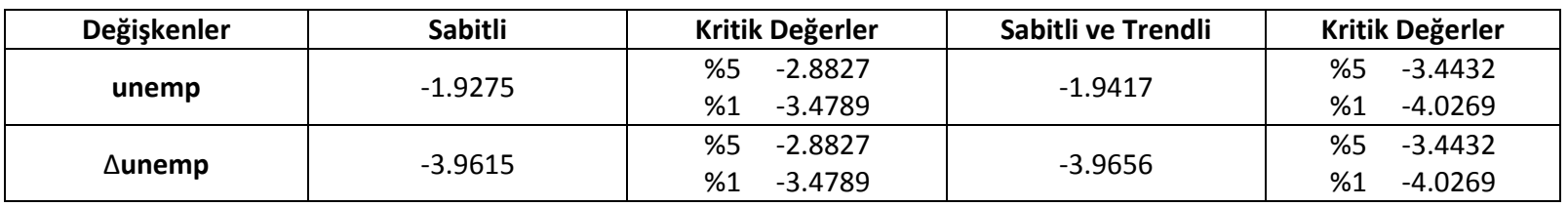

Tablo 3 PP birim kök sonuçlarını göstermektedir. Tablo 3'te yer alan sonuçlara göre işsizlik oranı hem sabitli modelde hem de sabitli ve trendli modelde seviyesinde birim kök içermektedir. İşsizlik oranları serisinin \%5 anlam düzeyinde birinci derecede durağan olduğu görülmektedir.

Tablo 3: PP Birim Kök Sonuçları

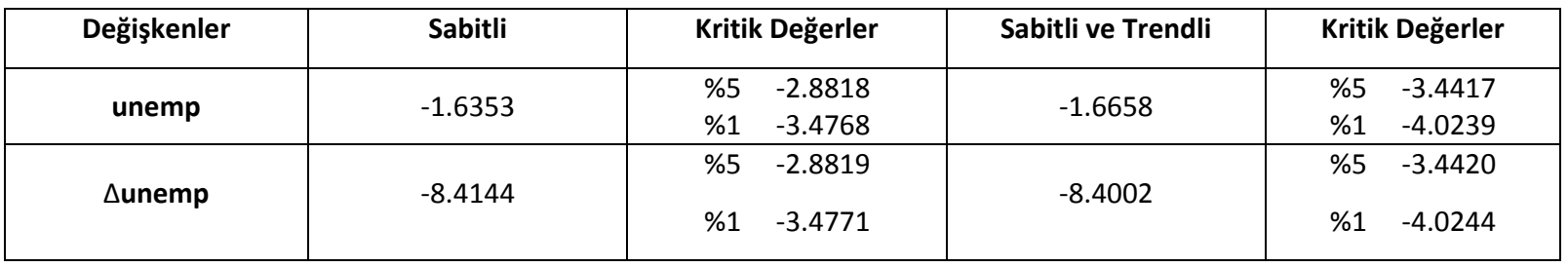

Tablo 4'te yer alan * işareti \%5 anlamlılık düzeyini ifade etmektedir. Kritik değerler, Lee ve Strazicich (2013), Lee Strazicich (2003) çalışmalarından elde edilmiştir. Her iki test için de $\lambda_{-} 1\left(T \_B 1 / T\right), \lambda \_2\left(T \_B 2 / T\right)$ şeklinde hesaplanarak birinci ve ikinci kırılma noktalarını ifade etmektedir.

Tablo 4: LS (2013) ve LS (2003) Testlerinin Sonuçları

\begin{tabular}{|c|c|c|c|c|}
\hline \multirow{2}{*}{} & \multicolumn{2}{|c|}{ LS (2013) } & \multicolumn{2}{c|}{ LS (2003) } \\
\cline { 2 - 5 } & Model A & Model C & $2009 \mathrm{~m} 11$ & $2008 \mathrm{~m} 10$ \\
\hline $\boldsymbol{T}_{\boldsymbol{B} 1}$ & $2009 \mathrm{~m} 11$ & $2010 \mathrm{~m} 8$ & $2010 \mathrm{~m} 2$ & $2011 \mathrm{~m} 6$ \\
\hline $\boldsymbol{T}_{\boldsymbol{B} 2}$ & - & - & 0.413 & 0.322 \\
\hline$\lambda_{1}$ & 0.413 & 0.476 & 0.434 & 0.545 \\
\hline$\lambda_{2}$ & - & - & -2.784 & $-5.802 *$ \\
\hline LM statistic & -2.486 & -3.188 & & \\
\hline
\end{tabular}

Tablo 4 incelendiğinde tek kırılmalı LS (2013) ve çift kırılmalı LS (2003) testleri görülmektedir. $T_{B 1}$ ilk kırılma tarihini gösterirken, $T_{B 2}$ ise ikinci kırılma tarihini ifade etmektedir. Tek kırılmalı testin Model A için sıfır hipotezi \%1, \%5 ve \%10 anlamlılık seviyelerinin tamamında kabul edilmektedir. Kırılma noktası analiz edilen dönemin ortalarında gerçekleşmiş olup 2008 küresel krizinin etkilerini barındırmaktadır. Tek kırımalı testin Model C kısmı incelendiğinde sıfır hipotezinin anlamlıık düzeylerinin tümünde kabul edildiği görülmektedir. Model $C^{\prime}$ de de kırılma noktası izlenen dönemin ortalarında yer almaktadır ve yine küresel krizin bu kırılmada etkili olduğu düşünülmektedir. Tek kırılmalı testlerde hem Model A hem de Model C'de işsizlik değişkeninin durağan bir sürece sahip olmadığı anlaşılmaktadır. Başka bir ifade ile tek kırılmalı LS (2013) testi ile ADF ve PP testlerinin sonuçları benzeşmekte ve Türkiye için işsizlik histerisi hipotezi kabul edilmektedir.

Çift kırılmalı LS (2003) testi Tablo 4 yardımıyla görülmektedir. Buna göre Model A incelendiğinde sıfır hipotezi \%1, \%5 ve \%10 anlam düzeylerinde kabul edilmektedir. Çift kırılmalı test Model A'da, kırılmalı test Model A ile benzerlik 
göstermektedir. Buna göre, ilk kırılma noktasının 2009 yılında gerçekleştiği görülürken, ikinci kırılma tarihi 2010 yılını göstermektedir. Tek kırılmalı testin her iki modeli de benzer şekilde 2009 ve 2010 tarihlerini göstermektedir. Çift kırılmalı test Model C'de \%1 anlam düzeyinde sıfır hipotezi kabul edilirken \%5 ve \%10 anlam düzeylerinde ise sıfır hipotezi ret edilmektedir. Kırılma tarihleri 2008 ve 2011 olarak tespit edilmiştir.

Incelenen yıllarda Türkiye için her iki LM tipi test sonuçlarına göre \%1 anlamlılık düzeyinde işsizlik histerisi hipotezi onaylanmaktadır. Başka bir deyişle Türkiye'de işsizlik histerisinin etkileri geçerlidir. Sonuç olarak Türkiye'de emek piyasalarında meydana gelen şoklar işsizlik oranları üzerinde kalıcı etkiler bırakmaktadır. Ayrıca yapısal kırılmaların tarihleri dikkate alındığında küresel krizin etkisinin izleri görülmektedir.

\section{SONUÇ}

Bu çalışmada Türkiye'deki işsizlik oranları üzerinde, doğal işsizlik oranı hipotezi mi yoksa işsizlik histerisi hipotezi mi geçerlidir sorusu analiz edilmiştir. Bunun için TÜik'ten elde edilen 2005 ve 2016 yıllarını kapsayan veriler kullanılmıştır. Bu amaçla ADF ve PP testleri kullanılmıştır. ADF ve PP testlerine ek olarak yapısal kırılmaları dikkate alan LS (2003) ve LS (2013) birim kök testleri de bu çalışmada kullanılmıştır.

İşsizlik sorunsalı Türkiye için özellikle 1980 sonrasında önemli bir hale gelmiştir. İşsizlik oranları bu dönemden itibaren artış eğilimine girmiştir. Özellikle kriz dönemi olan 2008 yıında işsizlik oranlarında yaşanılan hızlı artış göze çarpmaktadır. Yaşanılan krizden sonra işsizlik oranlarında bir düşüş yaşanmasına rağmen incelenen dönem ele alındığında işsizlik oranları dönemin başında ki oranlara tekrar düşmemiştir.

Çalışmada ulaşılan sonuçlara göre, yapısal kırılmaların dikkate alınmadığı ADF ve PP testlerinde işsizlik oranlarının seviye değerlerinde birim kök içerdiği bulunmuştur. ADF ve PP test sonuçlarına göre Türkiye'de işsizlik histerisi etkileri görülmektedir. Yapısal kırılmaları dikkate alan LS (2003) ve LS (2013) birim kök testleri de benzer şekilde sonuçlar vermiştir. Yapısal kırılmalı testlere göre de Türkiye işsizlik oranları verileri seviye değerlerinde durağan bir süreç içermemektedir. Yani işsizlik oranlarının geçmiş değerleriyle açıklandığı anlamına gelmektedir.

Yapısal kırılmaları dikkate alan LS(2003) ve LS (2013) testlerinin sonuçları incelendiğinde ise Türkiye'de işsizlik oranlarının 2008 küresel krizinden etkilendiği görülmektedir. Diğer bir ifade ile küresel boyutta ekonomileri derinden sarsan küresel finans krizinin ülkemizde de ciddi tahribatlara yol açtığı anlaşılmaktadır.

Sonuç olarak incelenen dönem ele alındığında Türkiye için işsizlik histerisi hipotezi kabul edilmektedir. Buna göre Türkiye'de gerçekleşen işsizlik oranları meydana gelen şoklara karşı dirençsizdir ve işsizlik oranlarında yaşanılan artış bir süre devam ettikten sonra eski denge düzeyine dönmeyerek yeni bir düzeyde dengelenme eğilimi gösterecektir. Başka bir ifadeyle işsizlik oranları ortaya çıkan şoklardan kalııı olarak etkilenmektedir. Dolayısıyla istihdam politikalarının uygulanmasında politika yapıcılar bu durumu dikkate almalıdır.

\section{KAYNAKLAR}

Akçay S. (2013). The Unemployment Hysteresis Analysis For Turkey. Yayımlanmamış Yüksek Lisans Tezi, ODTÜ, Ankara.

Arı A., Zeren F. ve Özcan B. (2013). Doğu Asya ve Pasifik Ülkelerinde İşsizlik Histerisi: Panel Veri Yaklaşımı. Marmara Üniversitesi iỉB Dergisi, 15(2), ss. 105-122.

Ball L.M. \& Mankiw N. G.(2002). The NAIRU in Theory and Practice. Journal of Economic Perspectives, 16(4), pp. 115-136.

Ball L.M. (2009). Hysteresis in Unemployment: Old and New Evidence. National Bureau of Economic Research Working Paper: 14818, pp. 137.

Barışık S. ve Çevik E. İ. (2008). Yapısal Kırılma Testleri ile Türkiye'de İşsizlik Histerisinin Analizi: 1923-2006 Dönemi. KMU iiBF Dergisi, 10(14), ss. 109-134.

Bayat T., Kayhan S. ve Koçyiğit A. (2013). Türkiye'de İşsizliğin Asimetrik Davranışının Rejim Değişim Modeliyle İncelenmesi. Business and Economics Research Journal, 4(2), ss. 79-90.

Baydur C. M. ve Süslü B. (2015). Türkiye'de NAIRU'yu Etkileyen Kısa ve Uzun Vadeli Etmenler. Business and Economics Research Journal, 6(1), ss. 43-62.

Bayrakdar S. (2015). Türkiye İçin İşsizlik Histerisi ya da Doğal İşsizlik Oranı Hipotezinin Geçerliliğinin Sınanması. İktisat Politikası Araştırmaları Dergisi, 2(2), ss. 45-61.

Berk E. ve Çağlar A. E. (2016). Türkiye'de İşsizlik Histerisi: Yapısal Kırılmalı Birim Kök Analizi. International Multidisciplinary Conference, Antalya , 21-22 April 2016 ,ss. 830-836.

Blanchard O. J. \& Summers L. H. (1986a). Hysteresis and the European Unemployment Problem. NBER Working Paper Series, 1, pp. $15-90$. 
Blanchard O. J. \& Summers L. H. (1986b). Hysteresis in Unemployment. NBER Working Paper, 31(1-2), pp. 1-12.

Cross, R., Hutchinson, H. \& Yeoward, S. (1990). The Natural Rate, Hysteresis, and the Duration Composition of Unemployment in the U.S. Quarterly Journal of Business and Economics, Vol. 29, N0. 2, pp. 89-116.

Edizdoğan N., Çetinkaya O. , Gümüş E. (2013). Kamu Maliyesi, Ekin Basım Yayın Dağıtım, 5. Baskı, Bursa.

Ewing J.A. (1881). The Effects of Stress on The Thermoelectric Quality of Metals. Part 1. Proceedings of the Royal Society of London 32, pp. 399-402.

Friedman M. (1968). The Role of American Monetary Policy. American Economic Review, 58, pp. 1-17.

Friedman M. (1977). Nobel Lecture: Inflation and Unemployment. Journal of Political Economy, 85(3), pp. 451-472.

Gustavsson M. \& Osterholm P. (2006). Hysteresis and Nonlinearities in Unemployment Rates. Applied Economics Letters, 13(9), pp. 545548.

Güloğlu B. ve İspir S. (2011). Doğal İşsizlik Oranı mı? İşsizlik Histerisi mi? Türkiye İçin Sektörel Panel Birim Kök Sınaması Analizi. Ege Akademik Bakış, 11, 2, ss. 205-215.

Hall, R.E. (1979). A Theory of the Natural Unemployment Rate and the Duration of Employment. Journal of Monetary Economics, Vol. 5, pp. 153-169.

Hiç-Birol, Ö. (2006). Keynesgil Sistem'in Gelişmesi. İstanbul Üniversitesi İktisat Fakültesi Mecmuası, 56(1), ss. $131-162$.

Lee J. \& Strazicich M. C. (2003). Minimum Lagrange Multiplier Unit Root Test With Two Structural Breaks.The Review of Economics and Statistics, 85(4), pp. 1082-1089

Lee J. \& Strazicich M. C. (2013). Minimum LM Unit Root Test With One Structural Break. Economic Bulletin, 33(4), pp. 2483-2492.

Modigliani F. \& Papademos L. (1975). Targets for Monetary Policy in the Coming Year. Brooking Papers on Economic Activity, 1, pp. 142165.

Modigliani, F. (2003). The Keynesian Gospel According to Modigliani. The American Economist, 47(1), pp. 3-24.

Phelps, E.S. (1967). Phillips Curves, Expectations of Inflation and Optimal Unemployment Over Time. Economica, 34(135), pp. 254-281.

Phelps, E.S. (1968). Money-Wage Dynamics and Labor-Market Equilibrium. Journal of Political Economy, 76(4) 2, Issues in Monetary Research, pp. 678-711.

Phelps E.S. (1972). Inflation Policy and Unemployment Theory: The Cost Benefit Approach To Monetary Planning, W.W. Norton, New York.

Røed, K. (1996). Unemployment Hysteresis-Macro Evidence From 16 OECD Countries. Empirical Economics, 21(4), pp. 589-600.

Romero-Avila D. \& Usabiaga C. (2007). Unit Root Tests and Persistence of Unemployment: Spain vs. the United States. Applied Economics Letters, 14(6), pp. 457-461

Samuelson P.A. (1965). Some Notions on Causality and Teleology in Economics. Reprinted in Merton R.C. (1972). The collected scientific papers of Paul A. Samuelson, Vol III, MIT Press, pp. 428-472.

Strazicich M. C.,Tieslau M. \& Lee J. (2001). Hysteresis in Unemployment? Evidence From Panel Unit Root Test With Strucrural Change. University of North Texas WorkingPaper, pp. 01-08.

Timurlenk, M.S. ve Başar, S. (2012). Türkiye İçin Enflasyonu Hızlandırmayan İşsizlik Oranı (NAIRU) Tahmini. Dokuz Eylül Üniversitesi i̇.i.B.F. Dergisi, 27(1), ss. 71-83.

Tobin, J. (1997). Supply Constrations om Employment and Output: NAIRU versus Natural Rate. Cowles Foundation Paper 1150, Yale University, New Haven.

Ulusoy A. (2013). Maliye Politikası, Celepler Matbaacılık, 7. Baskı, Trabzon.

Yalçınkaya Ö., Kaya V. (2017). Doğal İşsizlik Oranı Mı Yoksa; İşsizlik Histerisi Mi?: OECD Ülkeleri İçin Yeni Nesil Panel Birim Kök Testlerinden Kanıtlar (1980-2015). Selçuk Üniversitesi, İktisadi ve İdari Bilimler Fakültesi, Sosyal Ekonomik Araştırmalar Dergisi, 17(33), ss. 1-18.

Yılancı V. (2009). Yapısal Kırılmalar Altında Türkiye İçin İşsizlik Histerisinin Sınanması. Doğuş Üniversitesi Dergisi, 10, 2, ss. 324-335.

Yıldırım S. (2011). Türkiye'de Histeri Hipotezinin Geçerliliğinin Çoklu Yapısal Kırılmalı CKP Birim Kök Testiyle Sınanması. Akdeniz I.i..B.F. Dergisi, 22, ss. 28-47.

http://www.tuik.gov.tr/PreTablo.do?alt_id=1007, Erişim Tarihi: 07.03.2017. 